\title{
CONSPECTVS LIBRORVM
}

\section{Editiones}

A. Manutius, Philostrati de vita Apollonii Tyanei libri octo. Iidem libri latini interprete Alemano Rinuccino florentino. Eusebius contra Hieroclem qui Tyaneum Christo conferre conatus fuerit. Idem latinus interprete Zenobio Acciolo florentino ordinis praedicatorum, Venetiis 1501-1502.

F. Morel, Philostrati Lemnii opera quae extant. Philostrati iunioris Imagines, et Callistrati Ecphrases. Item Eusebii Caesariensis episcopi liber contra Hieroclem, qui ex Philostrati historia aequipararat Apollonium Tyaneum Salvatori nostro Iesu Christo, Parisiis 1608.

G. Olearius, Philostratorum quae supersunt omnia. Vita Apollonii libris VIII, Vitae Sophistarum libris II, Heroica, Imagines priores atque posteriores et Epistolae. Accessere Apollonii Tyanensis Epistolae, Eusebii Liber adversus Hieroclem, Callistrati descript. Statuarum, Lipsiae 1709.

C.L. Kayser, Flavii Philostrati quae supersunt. Philostrati Junioris Imagines. Callistrati descriptiones, Turici 1844 (= Kayser ${ }^{1}$; iterum impressum Turici 1853).

A. Westermann, Philostratorum et Callistrati opera, Parisiis 1849.

C.L. Kayser, Flavii Philostrati Opera, vol. I, Lipsiae $1870\left(=\mathrm{Kayser}^{2}\right)$.

F.C. Conybeare, Philostratus, The Life of Apollonius of Tyana. The Epistles of Apollonius and the Treatise of Eusebius, duo volumina, Cantabrigiae MA/Londinii 1912.

C.P. Jones, Philostratus, The Life of Apollonius of Tyana, duo volumina, Cantabrigiae MA/Londinii 2005.

\section{Translationes praecipuae}

A. Rinuccini, Philostratus, De vita Apollonii Tyanei, scriptor luculentus, a Philippo Beroaldo castigatus, Bononiae 1501.

F. Morel, 1608: vide Editiones.

G. Olearius, 1709: vide Editiones. 
F. Jacobs, Flavius Philostratus, des Aelteren, Werke, übersetzt von Hofrath Friedrich Jakobs, Band 2-5, Leben des Apollonius von Tyana, Stutgardiae 1829-1832 (iterum impressum Graecii 2017).

A. Westermann, 1849: vide Editiones.

A. Chassang, Apollonius de Tyane: Sa vie, ses voyages, ses prodiges, par Philostrate, Parisiis 1862.

F.C. Conybeare, 1912: vide Editiones.

J.S. Phillimore, Philostratus, In Honour of Apollonius of Tyana, duo volumina, Oxonii 1912.

C.P. Jones, Philostratus: Life of Apollonius. Translated by C.P. Jones, edited, abridged and introduced by G.W. Bowersock, Harmondsworth 1970.

D. del Corno, Filostrato. Vita di Apollonio di Tiana, Mediolani 1978 (iterum impressum 1988).

V. Mumprecht, Flavius Philostratus, Das Leben des Apollonius von Tyana, Monachii 1983.

A. Bernabé Pajares, Filóstrato: Vida de Apolonio de Tiana, Matriti 1992.

C.P. Jones, 2005: vide Editiones.

S. Mooij-Valk, Philostratus, Het leven van Apollonius van Tyana, Amstelodami 2013.

\section{Studia ad textus historiam constitutionemque pertinentia}

F.L. Abresch, Philippi Cattieri Gazophylacium Graecorum seu Methodus admirabilis, Lugduni Batavorum 1809.

J.C.F. Baehr, Ctesiae Cnidii operum reliquiae, Francofurti 1824.

D. Bain, An Emendation in Philostratus' Life of Apollonius of Tyana, LCM 19 (1994), 136.

G.J. Bekker, Specimen variarum lectionum et observationum in Philostrati Vitae Apollonii librum primum, Heidelbergae 1818.

J. Bentley, Notae manuscriptae in exemplaribus duobus editionis Morellianae in Bibliotheca Brittanica Londiniensi adservatis (678h8 et 679g1314).

S. Bochartus, Explicatio horum verborum Philostrati in Apollonio lib. 4. cap. 6. A $\mu \alpha \zeta o v \omega \nu \tilde{\alpha} \sigma \mu \alpha$, in idem, Opera omnia, editio quarta, Lugduni Batavorum/Traiecti ad Rhenum 1712, 1090-1093.

J.F. Boissonade, Flavius Philostratus, Heroica, Parisiis 1806. 
J.F. Boissonade, Eunapii Sardiani Vitas sophistarum et fragmenta historiarum recensuit notisque illustravit Io.Fr. Boissonade, Amstelodami 1822.

G.J. Boter, Towards a New Critical Edition of Philostratus' Life of Apollonius: The Affiliation of the Manuscripts, in K. Demoen \& D. Praet (edd.), Theios Sophistes. Essays on Flavius Philostratus' Vita Apollonii, Lugduni Batavorum/Bostoniae 2009, 21-56.

G.J. Boter, Studies in the Textual Tradition of Philostratus' Life of Apollonius of Tyana, RHT n.s. 9(2014), 1-49.

G.J. Boter, The Title of Philostratus' Life of Apollonius of Tyana, JHS 135 (2015), 1-7.

G.J. Boter, Editing Philostratus' Life of Apollonius of Tyana, in L. Ferroni (ed.), Tempus quaerendi. Nouvelles expériences philologiques dans le domaine de la pensée de l'Antiquité tardive, Parisiis 2019, $35-57$.

G.J. Boter, The Codex Vratislaviensis of Philostratus' Life of Apollonius of Tyana, Mnemosyne 73 (2020), 132-137.

E.L. Bowie, Apollonius of Tyana: Tradition and Reality, in ANRW 2.16.2, Berolini 1978, 1652-1699.

M. Casaubon, Notae in libro cui titulus Laertii Diogenis De Vitis Dogmatis et Apophthegmatis Eorum qui in Philosophia Claruerunt; Libri X. Thoma Aldobrandino interprete, Cum Annotationibus ejusdem. Quibus accesserunt Annotationes H. Stephani, et Utriusque Casauboni, Cum uberrimis Aegidii Menagii Observationibus, Londinii 1664.

C.G. Cobet, Miscellanea critica. Vita Apollonii Tyanensis, Mnemosyne 8 (1859), 77-80.

C.G. Cobet, Annotationes ad Philostratum I. Ad vitam Apollonii Tyanensis, Mnemosyne 8 (1859), 117-181.

E. Crisci, Ricerche sulla tradizione manoscritta della Vita di Apollonio di Tiana di Filostrato, dissertatio Universitatis Sapientiae, Romae 1983.

D. Erasmus, Adagiorum Chiliades, Basileae 1536.

T. Faber, Anacreontis et Sapphonis Carmina. Notas et animadversiones addidit Tanaquillus Faber, in quibus multa veterum emendantur, Salmurii 1680.

J. Fertig, De Philostratis sophistis, Bambergae 1894.

F. Grosso, Gli Eretriesi deportati in Persia, RFIC 36 (1958), 350-375.

J. Gruterus, Notae ab Oleario et Kaysero laudatae. 
S. Gsell, Essai sur le règne de l'empereur Domitien, Parisiis 1894.

T. Hägg, Photios als Vermittler antiker Literatur. Untersuchungen zur Technik des Referierens und Exzerpierens in der Bibliotheke, Upsaliae 1975.

T. Hägg, Bentley, Philostratus and the German Printers, JHS 102 (1982), 214-216.

H.A. Hamaker, Lectiones Pbilostrateae. Fasciculus primus, continens observationes in quatuor libros priores, et excursum in librum quartum de vita Apollonii, Lugduni Batavorum 1816.

W. Headlam, Various Conjectures III: Pbilostratus, JPh 23 (1895), 260-263.

T. Hemsterhuis, Nota a Kaysero laudata.

G. Hermann, Opuscula. Volumen tertium, Lipsiae 1828.

R. Holland, Zur Typik der Himmelfahrt, Archiv für Religionswissenschaft 23 (1925), 207-220.

L. Holstenius, Notae et castigationes in Stephanum Byzantium De urbibus, Lugduni Batavorum 1692.

P.D. Huet, Notae quas E. Miller ad Kayser misit (vide Kayser ${ }^{1}$, praefatio ad Vitam Apollonii, XV).

J. Jackson, Notae manuscriptae in exemplari editionis Conybearianae in bibliotheca viri docti Robert Parker Oxoniensis conservato.

F. Jacobs, Observationes in Aeliani historiam animalium et Pbilostrati vitam Apollonii; Epistola ad virum clarissimum Io. Gottlob Schneider, Ienae 1804 .

F. Jacobs, Additamenta animadversionum in Athenaei Deipnosophistas, Ienae 1809.

F. Jacobs, Philostratorum Imagines et Callistrati Statuae. Textum ad fidem veterum librorum recensuit et commentarium adiecit Fridericus Jacobs; observationes, archaeologici praesertim argumenti, addidit Fridericus Theopbilus Welcker, Lipsiae 1825.

F. Jacobs, Lectiones Stobenses sive supplementa lectionum ad Thomae Gaisfordii viri clarissimi editionem florilegii ethici. Praemissa est epistula ad Augustum Meineke virum clarissimum, Ienae 1827.

F. Jacobs, Ueber einige Stellen in Philostratus Leben des Apollonius, RhM 1828, 18-27.

F. Jacobs, Flavius Philostratus, des Aelteren, Werke, übersetzt von Hofrath Friedrich Jakobs, Band 2-5, Leben des Apollonius von Tyana, Stutgardiae 1829-1832 (iterum impressum Graecii 2017). 
F. Jacobs, Notae cum Kaysero communicatae (vide Kayser ${ }^{1}$, praefatio ad Vitam Apollonii, XV).

F. Jacoby, Die Fragmente der griechischen Historiker, Berolini 1923-.

G. Koen, Gregorius, Corinthi Metropolita, De dialectis, Lugduni Batavorum 1766.

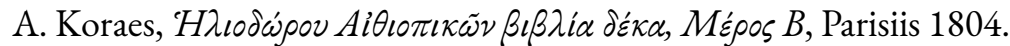

P. Leopardus, Pauli Leopardi Isembergensis Furnii, Emendationum et miscellaneorum libri viginti, in quibus plurima tam in Grecis quàm Latinis auctoribus à nemine bactenus animaduersa aut intellecta, explicantur $\Xi^{\circ}$ emendantur. Tomus prior, decem libros continens. Cum indice copiosissimo, Antverpiae 1568.

H.G. Liddell, R. Scott \& H.S. Jones, A Greek-English Lexicon, editio nona, Oxonii 1940.

C.A. Lobeck, Sophoclis Aiax, Berolini 1809.

C.A. Lobeck, Aglaophamus sive de theologiae mysticae Graecorum causis, idemque poetarum Orphicorum dispersas reliquias collegit, Regimontii 1829.

C.M. Lucarini, Ad Philostrati Vitam Apollonii, Hermes 132 (2004), 253-254.

J.N. Madvig, Adversaria critica ad scriptores Graecos et Latinos, I: De arte coniecturali, Emendationes graecae, Hauniae 1871.

A. Meineke, Menandri et Philemonis reliquiae, Berolini 1823.

A. Menagius, Notae in libro cui titulus Laertii Diogenis De Vitis Dogmatis et Apophthegmatis Eorum qui in Philosophia Claruerunt; Libri X. Thoma Aldobrandino interprete, Cum Annotationibus ejusdem. Quibus accesserunt Annotationes H. Stephani, et Utriusque Casauboni, Cum uberrimis Aegidii Menagii Observationibus, Londinii 1664.

J. Meurs, Eleusinia, sive de Cereris Eleusinae sacro ac festo liber singularis, Lugduni Batavorum 1619.

E. Miller, Recensio editionis Kayserianae anno 1844 Turici in lucem emissae necnon editionis Westermannianae anno 1849 Parisiis in lucem emissae, JS 1849, 616-632, 749-763.

C. Müller, Geographi Graeci minores, Volumen primum, Parisiis 1855.

S.A. Naber, Adnotationes criticae ad Longi Pastoralia, Mnemosyne 5 (1877), 199-220.

P. Nieuwland, Dissertatio de Musonio Rufo philosopho Stoico, in J.V. Peerlkamp, C. Musonii Rufi philosophi Stoici reliquiae et apophthegmata, Harlemi 1822, 7-137. 


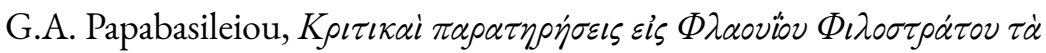

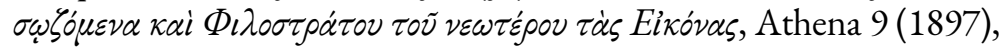
281-288.

R.J. Penella, The Letters of Apollonius of Tyana. A Critical Text with Prolegomena, Translation and Commentary, Lugduni Batavorum 1979.

N.S. Piccolos, Notae ad editionem Westermannianam cum E. Miller communicatae (vide Miller 1849).

J. Pierson, Moeridis Atticistae Lexicon Atticum, editio altera curante G.A. Koch, Lipsiae 1830.

A. Platt, Miscellanea, CQ 5 (1911), 256-257.

L. Preller, Recensio editionis Kayserianae anno 1844 in lucem emissae, Neue Jenaische allgemeine Literatur-Zeitung 5 (1846), 461-469.

L. Radermacher, Observationum et lectionum variarum specimen, Jahrbücher für classische Philologie 41 (1895), 253-256.

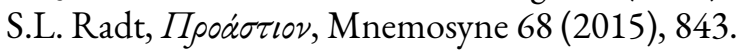

J.J. Reiske, Ad Philostratum animadversiones, inchoatum exeunte Decembri 1755, absolutum 3 Jan. 1756; Hauniae, Kongelige Bibliotek, ms. NKS 111 octavo. Vide Schenkl 1893.

J.J. Reiske, Ad Philostratorum Opera ex editione Olearii, inchoatum 12 Nov. 1769, absolutum 9 Febr. 1770, Hauniae, Kongelige Bibliotek, ms. NKS 111 octavo. Vide Schenkl 1893.

W. Rennie, Nota apud Phillimore.

J. Rhoer, Porphyrius De antro nympharum, ejusdem De abstinentia ab esu animalium libri quatuor, Lugduni Batavorum/Amstelodami 1792.

H. Richards, Notes on the Philostrati, CQ 3 (1909), 104-109.

D. Ruhnkenius, Timaei Sophistae Lexicon vocum Platonicarum, editio nova curante G.A. Koch, Lipsiae 1828.

C. Salmasius, Notae manuscriptae in exemplari editionis Morellianae in Bibliotheca Cantabrigiensi conservato (Nn.v.22).

J.J. Scaliger, Notae manuscriptae in exemplari editionis Aldinae in Bibliotheca Lugdunensi Batavorum conservato (760A5).

C. Scheibe, Recensio editionis Kayserianae anno 1844 in lucem emissae, Zeitschrift für Alterthumswissenschaft 5 (1847), 421-438.

C. Schenkl, Valckenarii animadversiones in Philostratos, WS 14 (1892), 267-277. 
C. Schenkl, Ioannis Iacobi Reiskii animadversiones in Pbilostratos, WS 15 (1893), 116-127.

W. Schmid, Der Attizismus in seinen Hauptvertretern von Dionysius von Halikarnass bis auf den zweiten Philostratus, Vierter Band, Stutgardiae 1896.

M. Solanus, Luciani Samosatensis opera Graece et Latine ad editionem Tiberii Hemsterbusii et Ioannis Frederici Reitzii accurate expressa cum varietate lectionis et annotationibus, Volumen tertium, Biponti 1790.

J. Toup, Notae in libro cui titulus Demosthenis oratio de corona, edidit Th.C. Harles, Altenburgi 1769.

J. Toup, Opuscula critica in quibus Suidas, et plurima loca veterum graecorum, Sophoclis, Euripidis, et Aristophanis in primis, cum explicantur, tum emaculantur, Lipsiae 1780-1781.

R. Unger, Thebana Paradoxa, Halis 1839.

L.C. Valckenaer, Herodoti Halicarnassei Historiarum libri IX (...). Editionem curavit et suas itemque Lud. Casp. Valckenarii notas adiecit Petrus Wesselingius, Amstelodami 1763.

L.C. Valckenaer, Notae in Philostrati Vitam Apollonii, Bibliotheca Lugdunensis Batavorum Q389. Vide Schenkl 1892.

L.C. Valckenaer, Callimachi elegiarum fragmenta, cum elegia Catulli Callimachea (...) edidit, praefatione atque indicibus instruxit Ioannes Luzac, Lugduni Batavorum 1799.

B.A. van Groningen, Notae manuscriptae in exemplari primae editionis Kayserianae in bibliotheca viri docti Jaap-Jan Flinterman Amstelodamensis conservato.

C.B. van Wulfften Palthe, Dissertatio litteraria continens observationes grammaticas et criticas in Philostratum, habita imprimis vitae Apollonii ratione, Lugduni Batavorum 1887.

P. Wesseling, Diodori Siculi Bibliothecae historicae libri qui supersunt, Amstelodami 1745-1746.

D. Wyttenbach, Epistola critica super nonnullis locis Iuliani imp. Accedunt animadversiones in Eunapium et Aristaenatum, ad virum celeberrimum Davidem Rubnkenium, Goettingae 1769.

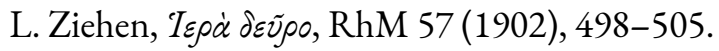




\section{Alia studia}

L. Abbondanza, La sophia e i saperi nella Vita di Apollonio di Tiana, in P. Vesperini (ed.), Philosophari : usages romains des savoirs grecs sous la République et sous l'Empire, Parisiis 2017, 467-486.

R.J. Abraham, Magic and Religious Authority in Philostratus' Life of Apollonius of Tyana, dissertatio Universitatis Pennsylvanianae 2009.

R.J. Abraham, The Geography of Culture in Philostratus' Life of Apollonius of Tyana, CJ 109 (2014), 465-480.

N. Adkin, Apollonius of Tyana in Jerome, Sacris Erudiri 39 (2000), 67-79.

M. Álvarez Martí-Aguilar, Talismans against Tsunamis: Apollonius of Tyana and the stelai of the Herakleion in Gades (VA 5.5), GRBS 57 (2017), 968-993.

G. Anderson, Philostratus: Biography and Belles Lettres in the Third Century A.D., Londinii 1986.

G. Anderson, The Second Sophistic: A Cultural Phenomenon in the Roman Empire, Londinii 1993.

G. Anderson, Sage, Saint, and Sophist: Holy Men and their Associates in the Early Roman Empire, Londinii 1994.

G. Anderson, Philostratus on Apollonius of Tyana: The Unpredictable on the Unfathomable, in G. Schmeling (ed.), The Novel in the Ancient World, Lugduni Batavorum/Novi Eboraci 1996, 613-618.

G. Anderson, Greek and Roman Folklore, Westportii 2006.

G. Anderson, Folklore versus Fakelore: Some Problems in the Life of Apollonius, in Demoen \& Praet 2009, 211-223.

G. Anderson, Fantasy in Greek and Roman Literature, Londinii/Novi Eboraci 2019.

J.M. André, Apollonios et la Rome de Néron, in M.-F. Baslez, Ph. Hoffmann \& M. Trédé-Boulmer (edd.), Le monde du roman grec. Actes $d u$ colloque international tenu à l'École normale supérieure (Paris 17-19 décembre 1987), Parisiis 1992, 113-124.

B. Bäbler \& H.-G. Nesselrath, Philostrats Apollonios und seine Welt. Griechische und nichtgriechische Kunst und Religion in der Vita Apollonii, Berolini/Bostoniae 2016.

R. Bailey, Arethas of Caesarea and the Scholia on Philostratus' Vita Apollonii in Codex Laurentianus Pluteus 69.33, Byzantion 86 (2016), 59-89. 
F.C. Baur, Apollonius von Tyana und Christus, oder das Verbältnis des Pythagoreismus zum Christentum: ein Beitrag zur Religionsgeschichte der ersten Jabrhunderte nach Christus, in E. Zeller (ed.), Drei Abhandlungen zur Geschichte der alten Philosophie und ibres Verhältnisses zum Christentum, Lipsiae $1876^{2}$ (Tubingae 1832'1).

L. Belloni, Aspetti dell' antica ropia in Apollonio di Tiana, Aevum 54 (1980), 140-149.

A.V. Belousov, On Some Possible Sources for Philostratus'Vita Apollonii 3.34, CQ 64 (2014), 787-792.

J.-L. Bernard, Apollonius de Tyane et Jésus, Parisiis 1977.

H.D. Betz, Gottmensch II (Griechisch-römische Antike u. Urchristentum), in RAC 12, Stutgardiae 1983, 234-312.

H.D. Betz, The Problem of Apocalyptic Genre in Greek and Hellenistic Literature: The Case of the Oracle of Trophonius, in D. Hellholm (ed.), Apocalypticism in the Mediterranean World and the Near East. Proceedings of the International Colloquium on Apocalypticism, Uppsala, August 12-17, 1979, Tubingae 1983, 577-597.

L. Bieler, $\Theta E I O \Sigma$ ANHP. Das Bild des "göttlichen Menschen" in Spätantike und Frübchristentum, Vindobonae 1935-1936.

A. Billault, Un sage en politique: Apollonios de Tyane et les empereurs romains, in F. Jouan \& A. Motte (edd.), Mythe et politique, Leodii 1990, 23-32.

A. Billault, Les formes romanesques de l'héroïsation dans la Vie d'Apollonios de Tyane de Philostrate, BAGB (1991), 267-274.

A. Billault, Le personnage de Philostrate dans la Vie d'Apollonios de Tyane : autoportrait de l'auteur en biographe, in M.-F. Baslez, P. Hoffmann \& L. Pernot (edd.), Invention de l'autobiographie d'Hésiode à Saint Augustin, Parisiis 1993, 271-278.

A. Billault, The Rhetoric of a "Divine Man": Apollonius of Tyana as Critic of Oratory and as Orator according to Philostratus, Ph\&Rh 26 (1993), 227-235.

A. Billault, Apollonios de Tyane en Espagne d'après le récit de Philostrate, in A. Billault (ed.), Héros et voyageurs grecs dans l'Occident romain, Lugduni 1997, 131-144.

A. Billault, L'Univers de Philostrate, Bruxellis 2000.

A. Billault, Les choix narratifs de Philostrate dans la Vie d'Apollonios de Tyane, in Demoen \& Praet 2009, 3-19. 
E. Birmelin, Die kunsttheoretischen Gedanken in Philostrats Apollonios, Lipsiae 1933.

B.E. Borg (ed.), Paideia: The World of the Second Sophistic, Berolini/ Novi Eboraci 2004.

Ph. Borgeaud, Trojan Excursions: A Recurrent Ritual, from Xerxes to Julian, HR 49 (2009-2010), 339-353.

S. Borzì, Sull' autenticità del Contra Hieroclem di Eusebio di Cesarea, Augustinianum 43 (2003), 397-416.

G.J. Boter, An Epicurean Message in Philostratus'Life of Apollonius of Tyana and Heroicus? An Evaluation of Peter Grossardt's Thesis, WJA 43 (2019), 107-136.

J. Boulogne, Apollonius de Tyane. Le mythe avorté d'une sagesse totale, BAGB (1999), 300-310.

G.W. Bowersock, Greek Sophists in the Roman Empire, Oxonii 1969.

G.W. Bowersock, The Miracle of Memnon, BASP 21 (1984), 21-32.

G.W. Bowersock, Philostratus and the Second Sophistic, in P.E. Easterling \& B.M.W. Knox (edd.), The Cambridge History of Classical Literature. I. Greek literature, Cantabrigiae 1985, 655-662.

G.W. Bowersock, Fiction as History. Nero to Julian, Berkeley 1994.

E.L. Bowie, Greeks and their Past in the Second Sophistic, in M. Finley (ed.), Studies in Ancient Society, Londinii 1974, 166-209.

E.L. Bowie, Apollonius of Tyana: Tradition and Reality, in ANRW 2.16.2, Berolini 1978, 1652-1699.

E.L. Bowie, Hellenes and Hellenism in Writers of the Early Second Sophistic, in S. Saïd (ed.), EAMHNISMOL: Quelques jalons pour une histoire de l'identité grecque, Lugduni Batavorum 1991.

E.L. Bowie, Philostratus: Writer of Fiction, in J.R. Morgan \& R. Stoneman (edd.), Greek Fiction. The Greek Novel in Context, Londinii/ Novi Eboraci 1994, 181-199.

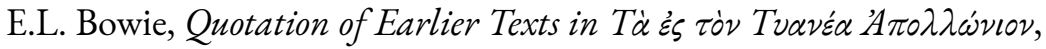
in Demoen \& Praet 2009, 57-73.

E.L. Bowie, Philostratus, the Life of a Sophist, in Bowie \& Elsner 2009, 19-32.

E.L. Bowie \& J. Elsner, Philostratus, Cantabrigiae 2009.

P. Brown, The Rise and Function of the Holy Man in Late Antiquity, JRS 61 (1971), 80-101.

A. Calderini, Teoria e pratica politica nella Vita di Apollonio di Tiana, RIL 74 (1940-1941), 213-241. 
A. Cameron, On Defining the Holy Man, in J. Howard-Johnston \& P. Hayward (edd.), The Cult of the Saints in Late Antiquity and the Middle Ages: Essays on the Contribution of Peter Brown, Oxonii 1999, 27-43.

E. Capettini, Nero the Viper: Zoological Lore and Political Critique in the Life of Apollonius of Tyana, AJPh 141 (2020), 635-664.

J. Charpentier, The Indian Travels of Apollonius of Tyana, Upsaliae 1934.

G. Corrington, The "Divine Man": His Origin and Functions in Hellenistic Popular Religion, Novi Eboraci 1986.

P. Cox, Biography in Late Antiquity: A Quest for the Holy Man, Berkeley \& Los Angeles 1983.

M. Crampon, Le bon roi selon Philostrate, in É. Smadja \& É. Geny Pouvoir (edd.), Pouvoir, divination, E̋ prédestination dans le monde antique, Parisiis 1999, 109-131.

C. Cremonesi, La vita pura: Apollonio di Tyana e la sapienza, Paduae 2005.

M. dall'Asta, Philosoph, Magier, Scharlatan und Antichrist. Zur Rezeption von Philostrats Vita Apollonii in der Renaissance, Heidelbergae 2008.

O. de Beauvoir Priaulx, The Indian Travels of Apollonius of Tyana, JAS 17 (1860), 70-105.

O. de Beauvoir Priaulx, The Indian travels of Apollonius of Tyana and the Indian Embassies to Rome, from the Reign of Augustus to the Death of Justinian, Londinii 1873.

L. de Lannoy, Flavii Philostrati Heroicus, Lipsiae 1977.

L. de Lannoy, Le problème des Philostrate, in ANRW 2.34.3, Berolini 1997, 2362-2448.

D. del Corno, Lo scritto di Filostrato su Apollonio Tianeo e la tradizione della narrativa, in A. Ceresa-Gastaldo (ed.), La struttura della fabulazione antica, Genuae 1979, 65-87.

K. Demoen, Philostratus, in K. de Temmerman \& E. van Emde Boas (edd.), Characterization in Ancient Greek Literature, Lugduni Batavorum/Bostoniae 2017, 503-520.

K. Demoen, Philostratus, in I.J.F. de Jong \& M.P. de Bakker, Speech in Ancient Greek Literature, Lugduni Batavorum/Bostoniae, sub prelo.

K. Demoen \& D. Praet (edd.), Theios Sophistes. Essays on Flavius Philostratus'Vita Apollonii, Lugduni Batavorum/Bostoniae 2009.

M.W. Dickie, Varia magica, Tyche 14 (1999), 57-76. 
M.W. Dickie, Magic and Magicians in the Greco-Roman world, Londinii/Novi Eboraci 2001.

K. Dowden, Kalasiris, Apollonios of Tyana and the Lies of Teiresias, in Panayotakis, Schmeling \& Paschalis 2015, 1-16.

J. Downie, Palamedes and the Wisdom of India in Philostratus' Life of Apollonius of Tyana, Mouseion 13 (2016), 65-83.

W.L. Dulière, Protection permanente contre des animaux nuisibles assurée par Apollonius de Tyane dans Byzance et Antioche. Évolution de son mythe, BZ 63 (1970), 247-277.

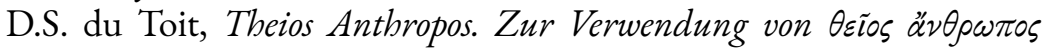
und sinnverwandten Ausdrücken in der Literatur der Kaiserzeit, Tubingae 1997.

D.S. du Toit, Die Vorstellung eines Begleitdämons in Philostrats Vita Apollonii, W\&D 25 (1999), 149-166.

M. Dzielska, Apollonius of Tyana in Legend and History, Romae 1986.

M.J. Edwards, Damis the Epicurean, CQ 41 (1991), 563-566.

J. Elsner, Hagiographic Geography: Travel and Allegory in the Life of Apollonius of Tyana, JHS 117 (1997), 22-37.

J. Elsner, A Protean Corpus, in Bowie \& Elsner 2009, 3-18.

J. Elsner, Beyond Compare: Pagan Saint and Christian God in Late Antiquity, Critical Inquiry 35 (2009), 655-683.

D. Esser, Formgeschichtliche Studien zur bellenistischen und frühchristlichen Literatur unter besonderer Berücksichtigung der vita Apollonii des Philostrat und der Evangelien, Bonnae 1969.

C.A. Faraone, Orpheus' Final Performance: Necromancy and a Singing Head on Lesbos, SIFC 2 (2004), 5-27.

V. Flint, R. Gordon, G. Luck \& D. Ogden (edd.), Witchcraft and Magic in Europe. Volume 2: Ancient Greece and Rome, Londinii 1999.

J.-J. Flinterman, Power, Paideia E Pythagoreanism: Greek Identity, Conceptions of the Relationship between Philosophers and Monarchs and Political Ideas in Philostratus' Life of Apollonius, trans. P. Mason, Amstelodami 1995.

J.-J. Flinterman, The Ubiquitous "Divine Man”, Numen 43 (1996), 82-98.

J.-J. Flinterman, Van Antiochië naar de Hellespont. Twee aardbevingen in Philostratus' Leven van Apollonius van Tyana, in J. Blok, J.-J. Flinterman \& L. de Ligt (edd.), Tesserae Romanae. Opstellen aangeboden aan Hans Teitler, Traiecti ad Rhenum 2002, 37-54. 
J.-J. Flinterman, Sophists and Emperors. A Reconnaissance of Sophistic Attitudes, in B. Borg (ed.), Paideia. The World of the Second Sophistic, Berolini/Novi Eboraci 2004, 359-376.

J.-J. Flinterman, Apollonius' Ascension, in Demoen \& Praet 2009, 225-248.

J.-J. Flinterman, 'The Ancestor of My Wisdom': Pythagoras and Pythagoreanism in Life of Apollonius, in Bowie \& Elsner 2009, 155-175.

J.-J. Flinterman, Pythagoreans in Rome and Asia Minor around the Turn of the Common Era, in C.A. Huffman (ed.), A History of Pythagoreanism, Cantabrigiae 2014, 341-359.

M. Forrat \& É. des Places, Eusèbe de Césarée, Contre Hiéroclès. Introduction, traduction et notes par M. Forrat, texte grec établi par É. des Places, Parisiis 1986.

J.A. Francis, Subversive Virtue: Asceticism and Authority in the SecondCentury Pagan World, Pennsylvaniae 1995.

J.A. Francis, Truthful Fiction: New Questions to Old Answers on Philostratus'Life of Apollonius, AJPh 119 (1998), 419-441.

V. Fromentin, La divination dans la Vie d'Apollonius de Tyane de Philostrate, in D. Briquel \& Ch. Guittard (edd.), La divination dans le monde étrusco-italique. 8, Des Sévères à Constantin : les écrivains du IIIe siècle et l'Etrusca disciplina. Actes de la table ronde tenue à l'ENS les 24 et 25 octobre 1997, Civitate Turonorum 1999, 71-79.

T. Fuhrer, 2004. Der alte Mann aus dem Meer: Zur Karriere des Verwandlungskünstlers Proteus in der Philosophie, in T. Fuhrer, P. Michel \& P. Stotz (edd.), Geschichten und ibre Geschichte, Basileae 2004, 11-36.

A. Galimberti, Apollonio di Tiana oppositore, in R. Cristofoli, A. Galimberti \& F. Rohr Vio (edd.), Lo spazio del non-allineamento a Roma fra tarda repubblica e primo principato: forme e figure dell'opposizione politica. Atti del convegno di studi: Milano 11-12 aprile 2013, Romae 2014, 227-243.

A. Galimberti, La Vita di Apollonio di Tiana $e$ Caracalla: cronologia e contesto storico, Aevum 88 (2014), 125-136.

M.W. Gleason, Making Men: Sophists and Self-Presentation in Ancient Rome, Princetoniae 1995.

A.A. González Terriza, El relato de la novia de Corinto (Philostr., "Vida de Apolonio" IV 25): esquema tipológico, Epos 32 (2016), 15-24.

J. Göttsching, Apollonius von Tyana, Lipsiae 1889. 
F. Graf, Maximos von Aigai. Beitrag zur Überlieferung von Apollonios von Tyana, JbAC 27 (1984-1985), 65-73.

F. Graf, Magic in the Ancient World, trans. F. Philip, Cantabrigiae MA/Londinii 1997.

P. Grossardt, Einfübrung, Übersetzung und Kommentar zum Heroikos von Flavius Philostrat. 1. Teilband: Einführung und Übersetzung; 2. Teilband: Kommentar, Basileae 2006.

P. Grossardt, How to Become a Poet? Homer and Apollonius Visit the Mound of Achilles, in Demoen \& Praet 2009, 75-94.

P. Grossardt, Philostr. VA 8,31 und die Frage nach der epikureischen Prägung des Corpus Philostrateum, WJA 38 (2014), 5-37.

P. Grossardt, Ironische Strukturen in Flavius Philostrats Vita Apollonii: der Besuch des Weisen in Indien und die Parallelisierung seines Lebenswegs mit dem des Odysseus, WJA 39 (2015), 93-135.

F. Grosso, La Vita di Apollonio di Tiana come fonte storica, Acme 7 (1954), 331-532.

W. Gyselinck, Pinning down Proteus: Thoughts on an Innovative Interpretation of Philostratus' Vita Apollonii, AC 76 (2007), 195-203.

W. Gyselinck, Talis oratio, qualis vita. Een tekstpragmatisch onderzoek naar de poëtica van Flavius Philostratus' Vita Apollonii, dissertatio Universitatis Gandianae (2008), https://biblio.ugent.be/publication/ 471670/file/4334622.pdf.

W. Gyselinck \& K. Demoen, Author and Narrator: Fiction and Metafiction in Philostratus' Vita Apollonii, in Demoen \& Praet 2009, 95-127.

T. Hägg, Hierocles the Lover of Truth and Eusebius the Sophist, SO 67 (1992), 138-150.

T. Hägg, Parthenope. Selected Studies in Ancient Greek Fiction, Hauniae 2004.

T. Hägg, The Art of Biography in Antiquity, Cantabrigiae 2012.

T. Hägg, The Sense of Travelling: Philostratus and the Novel, in K. Chew, S.M. Trzaskoma \& J.R. Morgan (edd.), Literary Currents and Romantic Forms: Essays in Memory of Bryan Reardon, Groningae 2018, 213-236.

J. Hahn, Der Philosoph und die Gesellschaft: Selbstverständnis, öffentliches Auftreten und populäre Erwartungen in der hohen Kaiserzeit, Stutgardiae 1989. 
J. Hahn, Weiser, göttlicher Mensch oder Scharlatan? Das Bild des Apollonius von Tyana bei Heiden und Christen, in B. Aland, J. Hahn \& C. Ronning (edd.), Literarische Konstituierung von Identifikationsfiguren in der Antike, Tubingae 2003, 87-110.

G.C. Hansen, Alexander und die Brabmanen, Klio 43-45 (1965), 351-380.

O. Hansen, $A$ Note on the Epigram on Apollonius of Tyana, Eranos 81 (1983), 143.

P. Hanus, La vie d'Apollonius de Tyane: d'une géographie réelle à une géographie mythique, in J.-C. Carrière \& alii (edd.), Inde, Grèce ancienne, Parisiis 1995, 81-97.

P. Hanus, Apollonios de Tyane et la tradition du "theios aner", DHA 24 (1998), 200-231.

B.F. Harris, Apollonius of Tyana: Fact and Fiction, JRH 5 (1969), 189-199.

J. Hempel, Untersuchungen zur Überlieferung von Apollonius von Tyana, Holmiae 1920.

I.H. Henderson, Speech Representation and Religious Rhetorics in Philostratus'Vita Apollonii, SR 32 (2003), 19-37.

M. Hendry, Pythagoras' Previous Parents: Why Euphorbos? Mnemosyne 48 (1995), 210-211.

P. Herrmann, Demeter Karpophoros in Sardeis, REA 100 (1998), 495-508.

G. Holtz, Paganisme et humanisme : la Renaissance française au miroir de la Vie d'Apollonius de Tyane, Parisiis 2021.

T. Hopfner, Apollonios von Tyana und Philostratos, Seminarium Kondakovianum 4 (1931), 135-164.

T. Hopfner, Die Brabmanen Indiens und die Gymnosophisten Ägyptens in der Apolloniosbiographie des Philostratos, ArchOrient 6 (1934), $58-67$.

N. Horsfall, Apuleius, Apollonius of Tyana, Bibliomancy: Some Neglected Dating Criteria, in G. Bonamente \& G. Paci (ed.), Historia Augusta Colloquium Maceratense, Barii 1995, 169-177.

S. Jackson, Apollonius and the Emperors, Hermathena 137 (1984), 25-32.

A. Jacquel, Une histoire de peste on Retour sur l'horrible miracle d'Apollonios de Tyane, DHA 43 (2017), 33-53. 
K. Jażdżewska, Plutarch and Atticism: Herodian, Phrynichus, Philostratus, in S. Xenophontos \& A. Oikonomopoulou (edd.), Brill's Companion to the Reception of Plutarch, Lugduni Batavorum/Novi Eboraci 2019, 66-78.

J. Jessen, Apollonius von Tyana und sein Biograph Philostratus, Hamburgi 1885.

C.P. Jones, An Epigram on Apollonius of Tyana, JHS 100 (1980), 190-194.

C.P. Jones, A Martyria for Apollonius of Tyana, Chiron 12 (1982), 137-144.

C.P. Jones, Apollonius of Tyana's Passage to India, GRBS 42 (2001), 185-200.

C.P. Jones, Apollonius of Tyana: Hero and Holy Man, in E.B. Aitken \& J.K.B. Maclean (edd.), Philostratus's Heroikos. Religion and Cultural Identity in the Third Century CE, Atlantae 2004, 75-84.

C.P. Jones, Philostratus: The Life of Apollonius of Tyana, Cantabrigiae CA/Londinii 2005.

C.P. Jones, Philostratus: Apollonius of Tyana. Letters of Apollonius, Ancient Testimonia, Eusebius' Reply to Hierocles, Cantabrigiae CA/ Londinii 2006.

C.P. Jones, Institutions and Cults in the Letters of Apollonius of Tyana, Studi Ellenistici 19 (2006), 599-613.

C.P. Jones, Apollonius of Tyana in Late Antiquity, in S.F. Johnson (ed.), Greek Literature in Late Antiquity: Dynamism, Didacticism, Classicism, Londinii 2006, 49-64.

C.P. Jones, Some Letters of Apollonius of Tyana, in Demoen \& Praet 2009, 249-261.

C.P. Jones, A Philosophical Altercation (Philostratus, Vita Apollonii V.39), Studi Ellenistici 24 (2010), 251-254.

E. Junod, Polémique chrétienne contre Apollonius de Tyane, RThPh 120 (1988), 475-482.

P.J. Kakridis, Odysseus und Palamedes, in Ø. Andersen \& M. Dickie (edd.), Homer's World: Fiction, Tradition, Reality, Bergen 1995, 91-100.

N. Kanavou, Philostratos' Life of Apollonios of Tyana and its Literary Context, Monachii 2018.

D. Kasprzyk, Letters in Philostratus' Life of Apollonius of Tyana, in O. Hodkinson, P.A. Rosenmeyer \& E.M.J. Bracke (edd.), Epistolary 
Narratives in Ancient Greek Literature, Lugduni Batavorum/ Bostoniae 2013, 263-289.

A.M. Kemezis, Greek Narratives of the Roman Empire under the Severans. Cassius Dio, Philostratus and Herodian, Cantabrigiae 2014.

A.M. Kemezis, Roman Politics and the Fictional Narrator in Philostratus'Apollonius, ClAnt 33 (2014), 61-101.

A.M. Kemezis, The Biographer as Literary Artist: Form and Content in Philostratus' Apollonius, in K. de Temmerman (ed.), The Oxford Handbook of Ancient Biography, Oxonii 2020, 235-250.

T.G. Knoles, Literary Technique and Theme in Philostratus'Life of Apollonius of Tyana, dissertatio Universitatis cui nomen Rutgers 1981.

E. Koskenniemi, Die religiösen Tendenzen des Philostratos in der Vita Apollonii Tyanensis, in H. Koskenniemi, S. Jäkel \& V. Pyykkö (edd.), Literatur und Philosophie in der Antike, Turku 1986, 107-117.

E. Koskenniemi, Der philostrateische Apollonios, Helsingfordiae 1991.

E. Koskenniemi, Apollonios von Tyana in der neutestamentlichen Exegese: Forschungsbericht und Weiterführung der Diskussion, Tubingae 1994.

E. Koskenniemi, Apollonius of Tyana: A Typical Theios Aner? JBL 117 (1998), 455-467.

E. Koskenniemi, The Old Testament Miracle-Workers in Early Judaism, Tubingae 2005.

E. Koskenniemi, The Philostratean Apollonius as a Teacher, in Demoen \& Praet 2009, 321-334.

G.M. Lee, Had Apollonius of Tyana Read St. Mark?, SO 48 (1973), 115-116.

F.W. Lenz, Die Selbstverteidigung eines politischen Angeklagten. Untersuchungen zu der Rede des Apollonios von Tyana bei Philostratos, Altertum 10 (1964), 95-110.

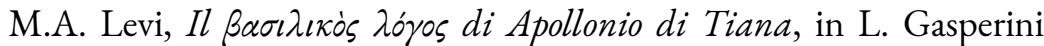
(ed.), Scritti sul mondo antico in memoria di Fulvio Grosso, Romae 1981, 289-293.

B. Levick, Julia Domna: Syrian Empress, Londinii 2007.

S.M. Lizcano Rejano, Orfismo en el Corpus Philostrateum, Eremita 71 (2003), 51-72.

F. Lo Cascio, La forma letteraria della Vita di Apollonio Tianeo, Panormi 1974. 
F. Lo Cascio, Sulla autenticità delle epistole di Apollonio Tianeo, Panormi 1978.

F. Lo Cascio, Apollonio Tianeo: Epistole e frammenti. Traduzione italiana con introduzione e note a cura di F. Lo Cascio, Panormi 1984.

F. Lo Cascio, Una allusione ad Apollonio di Tiana in Eusebio (Vita di Costantino III,56), Maia 37 (1985), 271-272.

E. Manolaraki, Noscendi Nilum cupido: Imagining Egypt from Lucan to Philostratus, Berolini/Bostoniae 2013.

H. Manthegi, The King and the Wizard: Apollonius of Tyana in the Iskandarnama of Niizami Ganjavi (1141-1209), in R. Stoneman, K. Nawotka \& A. Wojciechowska (edd.), The Alexander Romance, Groningae 2018, 63-68.

M. Marcovich, The Epigram on Apollonius of Tyana, ZPE 45 (1982), 263-265.

M.-F. Marein, Écriture fictionnelle de l'Histoire dans la Vie d'Apollonios de Tyane de Philostrate, in B. Morin (ed.), Polumathès / $\pi 0 \lambda v$ $\mu a \theta$ '́s : mélanges offerts à Jean-Pierre Levet, Civitate Lemovicum 2012, 327-342.

M.-F. Marein, La langue grecque en terre barbare au Ier s. ap. J.-C. dans La vie d'Apollonios de Tyane de Philostrate, in A. Garcea, M.-K. Lhommé \& D. Vallat (edd.), Polyphonia Romana : hommages à Frédérique Biville, Hildesiae/Turici 2013, 459-468.

M.-F. Marein, Jambe désenferrée, critique déchaînée : la réception de la Vie d'Apollonios de Tyane de Philostrate aux XVIe et XVIIe siècles, in C. Bost-Pouderon \& B. Pouderon (edd.), La réception de l'ancien roman: de la fin du Moyen Âge au début de l'époque classique. Actes du colloque de Tours, 20-22 octobre 2011, Lugduni 2015, 223-236.

P. Mascoli, Sulle opere perdute di Sidonio Apollinare, AFLB 47 (2004), 187-198.

A. Mendelson, Eusebius and the Postbumous Career of Apollonius of Tyana, in H.W. Attridge \& G. Hata (edd.), Eusebius, Christianity, and Judaism, Lugduni Batavorum/Novi Eboraci 1992, 510-522.

R. Merkelbach, Das Epigramm auf Apollonius von Tyana, ZPE 41 (1981), 270.

R. Merkelbach, Deuterai Phrontides zu dem Epigramm auf Apollonios von Tyana, ZPE 45 (1982), 265-266.

J. Mesk, Die Damisquelle des Philostratos in der Biographie des Apollonios von Tyana, WS 41 (1919), 121-138. 
M. Meunier, Apollonius de Tyane ou le séjour d'un dieu parmi les hommes, Parisiis 1936.

E. Meyer, Apollonios von Tyana und die Biographie des Philostratos, Hermes 52 (1917), 371-424.

G. Miles, Humanity, Divinity and Animality in Philostratus' Life of Apollonius and Heroicus, dissertatio Universitatis Australiae Occidentalis 2005.

G. Miles, Reforming the Eyes: Interpreters and Interpretation in the Vita Apollonii, in Demoen \& Praet 2009, 129-160.

G. Miles, Incarnating Proteus in Philostratus' Life of Apollonius of Tyana, AncNarr 13 (2016), 139-157.

G. Miles, Hippolytus, the Lamia, and the Eunuch: Celibacy and Narrative Strategy in Philostratus' Life of Apollonius, CPh 112 (2017), 200-218.

G. Miles, Ominous Swans in Philostratus' Life of Apollonius (1.5), Mnemosyne 70 (2017), 758-774.

G. Miles, Philostratus, in Richter \& Johnson 2017, 273-290.

G. Miles, Philostratus: Interpreters and Interpretation, Londinii/Novi Eboraci 2018.

G. Miles \& K. Demoen, In Praise of the Fable: The Philostratean Aesop, Hermes 137 (2009), 28-44.

J. Miller, Die Beziehungen der Vita Apollonii zur Pythagorassage, Philologus 51 (1892), 137-145.

J. Miller, Zur Frage nach der Persönlichkeit des Apollonius von Tyana, Philologus 51 (1892), 581-584.

J. Miller, Die Damispapiere in Philostratos' Apolloniosbiographie, Philologus 66 (1907), 511-525.

C. Moreschini, La Vita di Apollonio di Tiana di Filostrato e la cultura filosofica e religiosa dell'età severiana, in E. Ceresa-Gastaldo (ed.), Biografia e agiografia nella letteratura cristiana antica e medievale, Bononiae 1990, 43-63.

J.R. Morgan, The Emesan Connection: Philostratus and Heliodorus, in Demoen \& Praet 2009, 263-281.

T.J. Morgan, Encyclopaedias of virtue? Collections of Sayings and Stories about Wise Men in Greek, in J. König \& G. Woolf (edd.), Encyclopaedism from Antiquity to the Renaissance, Cantabrigiae/Novi Eboraci 2013, 108-128. 
C. Muckensturm-Poulle, Désincarnation et réincarnation des âmes dans la Vie d'Apollonios de Tyane, in G. Ducœur \& C. Muckensturm-Poulle (edd.), La transmigration des âmes en Grèce et en Inde anciennes, Vesontione 2016, 107-122.

K. Münscher, Die Philostrate, Philologus Supplementband 10 (1907), 467-558.

H.-G. Nesselrath, Philostratus' Apollonius in Imperial Athens: Old Values and Modern Decadence, in I. Tanaseanu-Döbler \& L. von Alvensleben (edd.), Athens II: Athens in Late Antiquity, Tubingae 2020, 59-72.

H.-G. Nesselrath, Von falscher und von wabrer Autorität: Die charismatischen religiösen Figuren Alexander von Abonuteichos, Peregrinos Proteus und Apollonios von Tyana im Diskurs der Zweiten Sophistik, in P. Gemeinhardt \& T.S. Scheer (edd.), Autorität im Spannungsfeld von Bildung und Religion, Tubingae 2021, 115-134.

C. O'Brien, The Philosophy of Apollonius of Tyana: An Attempt at Reconstruction, Dionysius 27 (2009), 17-31.

C. Padilla, Los milagros de la "Vida de Apolonio de Tiana": morfología del relato de milagro y géneros afines, Cordubae 1991.

C. Padilla, Hombres divinos y taumaturgos en la antigüedad. Apolonio di Tiana, in A. Piñero Sáenz (ed.), En la frontera de lo imposible. Magos, médicos y taumaturgos en el Mediterráneo antiguo en tiempos del Nuevo Testamento, Cordubae \& Matriti 2001, 141-162.

J. Palm, Om Filostratos och hans Apollonios-biografi, Upsaliae 1976.

S. Panayotakis, G.L. Schmeling \& M. Paschalis (edd.), Holy Men and Charlatans in the Ancient Novel, Groningae 2015.

D. Panchenko, Scylax in Philostratus' Life of Apollonius of Tyana, Hyperboreus 8 (2002), 5-12.

M. Paschalis, Apollonius of Tyana as Proteus: theios anēr or Master of Deceit?, in Panayotakis, Schmeling \& Paschalis 2015, 133-150.

H. Paulsen, Die Wunderüberlieferung in der Vita Apollonii des Philostratos, in id., Zur Literatur und Geschichte des früben Christentums, Gesammelte Aufsätze, herausgegeben von U.E. Eisen, Tubingae 1997, 220-234.

Th. Paulsen, Verherrlichung und Verspottung: die Gestalt des 'Gottmenschen' bei Philostrat und Lukian, in B.E.G. Binder, B. Effe \& R.F. Glei (edd.), Gottmenschen: Konzepte existentieller Grenzüberschreitung im Altertum, Augustae Treverorum 2003, 97-120. 
W. Peek, Epigramm auf Apollonios von Tyana, Philologus 125 (1981), 297-298.

J. Peláez \& C. Padilla, Espacio, tiempo y adversidad en los relatos de milagro del Evangelio de Marcos y de la Vida de Apolonio de Tiana de Flavio Filóstrato, Fortunatae 20 (2009), 101-126.

R.J. Penella, Scopelianus and the Eretrians in Cissia, Athenaeum 52 (1974), 295-300.

R.J. Penella, An Unpublished Letter of Apollonius of Tyana to the Sardians, HSPh 79 (1975), 305-311.

R.J. Penella, An Overlooked Story about Apollonius of Tyana in Anastasius Sinaita, Traditio 34 (1978), 414-415.

R.J. Penella, The Letters of Apollonius of Tyana. A Critical Text with Prolegomena, Translation and Commentary, Lugduni Batavorum 1979.

R.J. Penella, Philostratus' Letter to Julia Domna, Hermes 107 (1979), 161-168.

R.J. Penella, Apollonius of Tyana and Apollonides of Caesarea Maritima, AJPh 102 (1981), 423-424.

R.J. Penella, Anacharsis in a Letter of Apollonius of Tyana, CQ 38 (1988), 570-572.

R.J. Penella, Koddaroi and Xuresitauroi in the Letters of Apollonius of Tyana: New Evidence for Tension between Jews and Gentiles in Sardis during the Flavian Period? JJS 66 (2015), 231-241.

G. Petzke, Die Traditionen über Apollonius von Tyana und das Neue Testament, Lugduni Batavorum 1970.

V. Platt, Virtual Visions: Phantasia and the Perception of the Divine in The Life of Apollonius of Tyana, in Bowie \& Elsner 2009, 131-154.

V. Platt, Facing the Gods: Epiphany and Representation in GraecoRoman Art, Literature and Religion. Greek Culture in the Roman World, Cantabrigiae/Novi Eboraci 2011.

D. Praet, Pythagoreanism and the Planetary Deities: The Philosophical and Literary Master-structure of the Vita Apollonii, in Demoen \& Praet 2009, 283-320.

D. Praet, Earnest Play: Religion, Rhetoric and Intertextuality in the Life of Apollonius of Tyana by Flavius Philostratus, in I. Volt \& J. Päll (edd.), Quattuor Lustra: Papers Celebrating the 20th Anniversary of the Re-establishment of Classical Studies at the University of Tartu, Tartu 2012, 109-126. 
D. Praet, Inclusivité et exclusivité dans la Vie d'Apollonius de Tyane : Philostrate sur le judaïme, le christianisme et les traditions païennes, RHR 234 (2017), 661-688.

D. Praet, K. Demoen \& W. Gyselinck, Domitian and Pentheus, Apollonius and Dionysos: Echoes of Homer and of Euripides' Bacchae in Philostratus'Vita Apollonii, Latomus 70 (2011), 1058-1067.

D. Praet, Death and the Maiden in Philostratus, About Apollonius of Tyana 4.45. Miracle, Mystery or Philosophical Skepticism?, Mnemosyne, sub prelo.

I. Prchlík, Sidonius or Flavianus: By Whom was Philostratus' Vita Apollonii translated into Latin?, GLP 22 (2007), 199-210.

O. Primavesi \& L. Giuliani, Bild und Rede: Zum Proömium der Eikones des zweiten Philostrat, Poetica 44 (2012), 25-79.

J. Puiggali, La démonologie de Philostrate, RSPh 67 (1983), 117-130.

I. Puskás, Myth or Reality: Apollonius of Tyana in India, ACD 27 (1991), 115-123.

J. Raeymaekers, The Grain Hoarders of Aspendus. Philostratus on the Intervention of Apollonius of Tyana (Vita Apollonii I 15), in L. Mooren (ed.), Politics, Administration and Society in the Hellenistic and Roman world. Proceedings of the International Colloquium, Bertinoro 19-24 July 1997, Lovaniae 2000, 275-286.

D.H. Raynor, Moeragenes and Philostratus: Two Views of Apollonius of Tyana, CQ 34 (1984), 222-226.

G.L. Reger, On the Road to India with Apollonios of Tyana and Thomas the Apostle, in I. Malkin (ed.), Greek and Roman Networks in the Mediterranean, Londinii 2009, 249-263.

G.L. Reger, Apollonios of Tyana and the Gymnoi of Ethiopia, in M.P. Futre Pinheiro \& S. Montiglio (edd.), Philosophy and the Ancient Novel, Groningae 2015, 141-157.

A.M. Reimer, Miracle and Magic. A Study in the Acts of the Apostles and the Life of Apollonius of Tyana, Londinii/Novi Eboraci 2002.

R. Reitzenstein, Hellenistische Wundererzäblungen, Lipsiae 1906.

N.J. Richardson \& P. Burian, The Epigram on Apollonius of Tyana, GRBS 22 (1981), 283-285.

D.S. Richter \& W.A. Johnson (edd.), The Oxford Handbook of the Second Sophistic, Novi Eboraci 2017.

P. Robiano, Les Gymnosophistes éthiopiens chez Philostrate et chez Héliodore, REA 94 (1992), 413-428. 
P. Robiano, Philostrate et la chevelure d'Apollonios de Tyane, Pallas 41 (1994), 57-65.

P. Robiano, Apollonios de Tyane, in R. Goulet (ed.), Dictionnaire des philosophes antiques. Tome I: Abam(m)on à Axiothéa, Parisiis 1994, 289-294.

P. Robiano, Philostrate émule d'Arrien ? Le cas de la Vie d'Apollonios de Tyane, REG 109 (1996), 489-505.

P. Robiano, L'épigramme sur Apollonios de Tyane et Alexandre, le faux prophète, EA 33 (2001), 81-83.

P. Robiano, Un discours encomiastique : en l'honneur d'Apollonios de Tyane, REG 114 (2001), 637-646.

P. Robiano, Lecture silencieuse ou lecture privée ?: à propos d'une interprétation récente de Pbilostrate, V. Apoll. V 38, REG 117 (2004), 336-340.

P. Robiano, Entre réalité et fiction. La frontière égypto-éthiopienne chez Aelius Aristide, Xénophon d'Éphèse, Philostrate et Héliodore d'Émèse, Kentron 27 (2011), 131-150.

P. Robiano, Le théatre dans la Vie d'Apollonios de Tyane de Philostrate, REA 97 (2015), 193-209.

P. Robiano, Les Judéens dans la Vie d'Apollonios de Tyane de Pbilostrate, Studi Ellenistici 29 (2015), 321-337.

P. Robiano, Philostrate, sur la mort de Titus : Essai d'interprétation, Latomus 75 (2016), 482-487.

P. Robiano, The Apologia as a mise-en-abyme in Philostratus' Life of Apollonius of Tyana, in K. de Temmerman \& K. Demoen (edd.), Writing Biography in Greece and Rome, Cantabrigiae 2016, 97-116.

P. Robiano, Tous Tyriens ?: Réflexions sur l'identité tyro-phénicienne dans l'euvre de Flavius Philostrate, REA 119 (2017), 141-166.

É. Romieux-Brun, L'évocation des Perses dans la Vie d'Apollonios de Tyane de Philostrate : Une représentation de l'identité grecque sous l'empire, BAGB 2013, 112-126.

H. Rommel, Die naturwissenschaftlich-paradoxografischen Exkurse bei Philostratos, Heliodoros und Achilles Tatios, Stutgardiae 1923.

G. Sauron, Quis deum ? L'expression plastique des idéologies politiques et religieuses à Rome, Romae 1994.

T. Schirren, Philosophos Bios: die antike Philosophenbiographie als symbolische Form. Studien zur Vita Apollonii des Philostrat, Heidelbergae 2005. 
T. Schirren, Irony versus Eulogy. The Vita Apollonii as Metabiographical Fiction, in Demoen \& Praet 2009, 161-186.

G.L. Schmeling (ed.), The Novel in the Ancient World, Lugduni Batavorum 1996.

Th.A. Schmitz, Bildung und Macht. Zur sozialen und politischen Funktion der zweiten Sophistik in der griechischen Welt der Kaiserzeit, Monachii 1997.

Th.A. Schmitz, Performing History in the Second Sophistic, in M. Zimmermann (ed.), Geschichtschreibung und politischer Wandel im 3. Jh. n.C., Stutgardiae 1999, 71-92.

Th.A. Schmitz, In the Temple of Daphnean Apollo: "Philostratus" in His Works, in G. Bitto \& B.M. Gauly (edd.), Auf der Suche nach Autofiktion in der antiken Literatur, Berolini/Bostoniae 2021, 193-212.

G. Schwarz, Achill und Polyxena in der römischen Kaiserzeit, $\operatorname{MDAI}(\mathrm{R})$ 99 (1992), 265-299.

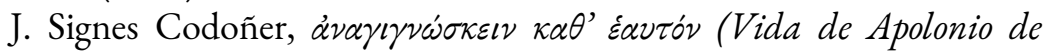
Tiana 5.38), Minerva 12 (1998), 103-108.

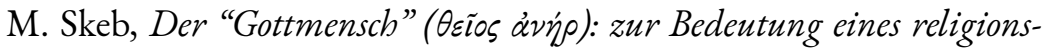
geschichtlichen Deutemusters für das Verständnis christlicher Leitfiguren der Spätantike, RQA 108 (2013), 153-170.

M. Skotheim, "Naked Competitions." Reading and Misreading Greek Festival Culture in Philostratus'Life of Apollonius of Tyana, Eranos 110 (2019), 107-124.

V.A. Smith, The Indian Travels of Apollonius of Tyana, ZDMG 68 (1914), 329-344.

F. Solmsen, Some Works of Philostratus the Elder, TAPhA 71 (1940), 556-572.

F. Solmsen, Philostratos (9)-(12), in RE 20.1, Stutgardiae 1941, 124-177.

W. Speyer, Zum Bild des Apollonios von Tyana bei Heiden und Christen, JbAC 17 (1974), 47-63.

S. Swain, Apollonius in Wonderland, in D. Innes, H. Hine \& C. Pelling (edd.), Ethics and Rhetoric. Classical Essays for Donald Russell on his 75th Birthday, Oxonii 1995, 251-254.

S. Swain, Hellenism and Empire: Language, Classicism, and Power in the Greek World, AD 50-250, Oxonii 1996.

S. Swain, Defending Hellenism: Philostratus, In Honour of Apollonius, in M. Edwards, M. Goodman, S. Price \& C. Rowland (edd.), Apolo- 
getics in the Roman Empire. Pagans, Jews, and Christians, Oxonii 1999, 157-196.

S. Swain, Culture and Nature in Philostratus, in Bowie \& Elsner 2009, 33-46.

B.L. Taggart, Apollonius of Tyana: His Biographers and Critics, dissertatio Universitatis cui nomen Tufts 1972.

M. Thiébaut, Apollonios de Tyane et la tradition du "theios aner", DHA 24 (1998), 200-231.

A. Treloar, Aethiopians, Prudentia 4 (1972), 42-50.

J.M. Van Cangh, Santé et salut dans les miracles d'Épidaure, d'Apollonios de Tyane et du Nouveau Testament, in J. Ries, Y. Janssens \& J.M. Severin (edd.), Gnosticisme et monde hellénistique, Lovaniae 1982, 263-277.

L. Van der Stockt, "Never the Twain Shall Meet"? Plutarch and Philostratus' Life of Apollonius: Some Themes and Techniques, in Demoen \& Praet 2009, 187-208.

G.-J. van Dijk, The Odyssey of Apollonius: An Intertextual Paradigm, in Bowie \& Elsner 2009, 176-202.

D. van Sasse van Ysselt, Stradanus' Drawings for the Life of Apollonius of Tyana, Master Drawings 32 (1994), 351-359.

M. Van Uytfanghe, La Vie d'Apollonius de Tyane et le discours hagiographique, in Demoen \& Praet 2009, 335-374.

J.B. Weaver, Plots of Epiphany. Prison-Escape in Acts of the Apostles, Berolini/Novi Eboraci 2004.

O. Weinreich, Gebet und Wunder. Zwei Abhandlungen zur Religionsund Literaturgeschichte, in Genethliakon. Wilhelm Schmid zum 70. Geburtstag am 24. Februar 1929, Stutgardiae 1929, 169-464.

U. Weisser, Das “Buch über das Geheimnis der Schöpfung” von pseudoApollonius von Tyana, Berolini/Novi Eboraci 1980.

T.G.J. Whitmarsh, Greek Literature and the Roman Empire: The Politics of Imitation, Oxonii 2001.

T.G.J. Whitmarsh, Philostratus, in I.J.F. de Jong, R. Nünlist \& A. Bowie (edd.), Narrators, Narratees, and Narratives in Ancient Greek Literature, Lugduni Batavorum/Bostoniae 2004, 423-439.

T.G.J. Whitmarsh, The Second Sophistic, Oxonii 2005.

T.G.J. Whitmarsh, Philostratus, in I.J.F. de Jong \& R. Nünlist (edd.), Time in Ancient Greek Literature, Lugduni Batavorum/Bostoniae 2007, 413-430. 
T.G.J. Whitmarsh, Philostratus, in I.J.F. de Jong (ed.), Space in Ancient Greek Literature, Lugduni Batavorum/Bostoniae 2012, 463-479.

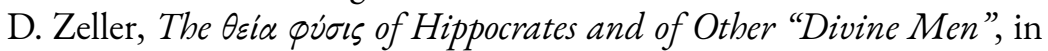
J.T. Fitzgerald, T.H. Olbricht \& L.M. White (edd.), Early Christianity and Classical Culture. Comparative Studies in Honor of Abraham J. Malherbe, Lugduni Batavorum/Bostoniae 2003, 49-69. 